\title{
Perspectives
}

\section{Minidoka: Artist as Witness: Images and Narrative in the Face of Fear}

\author{
John R. Ruff \\ Valparaiso University, Valparaiso, Indiana, USA \\ John.Ruff@valpo.edu
}

From 8 October 2016 through 15 January 2017, the Boise Art Museum in Boise, Idaho hosted an exhibition entitled Minidoka: Artist as Witness, curated by Nicole Herden and June Black. The Minidoka War Relocation Authority Center (also referred to as Minidoka) was an incarceration camp where approximately 13,000 Us residents of Japanese descent were detained during World War II, the majority of them American citizens. ${ }^{1}$ Three of the artists featured in the exhibition-Takuichi Fujii, Kenjiro Nomura, and Roger Shimomura-were detained there; two others - Wendy Maruyama and Teresa Tamura-were never sent to Minidoka, but they are connected to the camp through their art. The act of witnessing these artists provide, through their work on events that occurred more than seventy years ago has urgent relevance nationally and internationally, as the plight of immigrants and refugees fleeing violence and war becomes more dire each day, even as fear of global terrorism obstructs efforts to provide them aid and safe haven. Following his oft-cited 1933 statement that "the only thing we have to fear is fear itself," ${ }^{2}$ Franklin D. Roosevelt himself succumbed to wartime hysteria and signed United States Presidential Executive Order 9066

1 "Minidoka Concentration Camp: Looking Back 70 Years Later," Densho, 28 October 2015, accessed 7 July 2017, http://www.densho.org/minidoka-concentration-camp-looking-back -70-years-later.

2 Franklin D. Roosevelt, transcript of first inaugural address, 4 March 1933, in The Public Papers of Franklin D. Roosevelt, Volume Two: The Year of Crisis, 1933, ed. Samuel Rosenman (New York: Random House, 1938), 11-16. 
on 19 February 1942, authorizing the forced relocation and detention of up to 120,000 Japanese legal residents of the West Coast, more than half of them American-born citizens. Though a vast literature exists on the Japanese internment, many remain not only unaware it ever happened and ignorant of the great injustice and suffering that it caused, missing the lessons it might teach us about the treatment of immigrants in America, then and now. How the idea of the Yellow Peril was carefully planted, took root, and thrived is a sad, shameful chapter in the history of American immigration law that the world needs to betterunderstand. The arts may offer a means to address these wrongs, and confront the racism stemming from such xenophobic fear in ways that can change hearts and minds by providing witness. This essay contemplates these issues within the context of the Minidoka exhibition and in relation to the work of an obscure but recently rediscovered painter, Takuichi Fujii (1891-1964).

Organizers and curators of Minidoka:Artist as Witness could not have anticipated how timely and relevant their exhibition would turn out to be, given how explosive the issues of immigration and race became in the 2016 us election season, with Europe convulsed by the worst refugee crisis since World War II, regions around the globe destabilized by war, and the fear of global terrorism on the rise. The Minidoka exhibition opened in the midst of the us election campaign cycle, with Republican presidential candidate Donald Trump promising to deport 11 million undocumented immigrants, build a wall on the Mexican border, impose a ban on Syrian refugees, create a Muslim registry, and subject all applicants for immigration from "Muslim countries" to extreme vetting. The exhibition ended in January 2017, the day after Trump's inauguration as the 45th President of the United States.

The Minidoka Relocation Center, known more often to locals as Camp Hunt, was a sprawling, hastily built incarceration camp in a remote desert region of south-central Idaho. Sixty percent of the 13,00o men, women, and children detained there were American citizens, and the remaining forty percent legal permanent residents of the us. ${ }^{3}$ Among the detainees were three Minidoka exhibition artists. Takuichi Fujii (1891-1964) and Kenjiro Nomura (1896-1956) arrived from Seattle as adults, or Isse - - first-generation Japanese residents - who were already established artists when the war broke out. Seattle-born Roger Shimomura (b. 1936), a third-generation Japanese American or Sansei who later became a nationally acclaimed painter, arrived at the camp as a threeyear-old with his parents and grandparents. The other two Sansei artists in the exhibition, San Diego-based artist and fine arts furniture maker Wendy

3 "Minidoka Concentration Camp: Looking Back 70 Years Later," Densho, 28 October 2015, accessed 10July 2017, http://www.densho.org/minidoka-concentration-camp-looking-back-70 -years-later. 
Maruyama (b. 1952) and photojournalist Teresa Tamura (b. 196o), originally from Nampa, Idaho, grew up knowing relatively little about the Japanese incarceration, acquiring their knowledge of the camps only later on in life. Though Maruyama's family was directly affected by the incarceration, she reports her mother and grandparents never talked about it and that it was photographs by Dorothea Lange and Toyo Miyatake that sparked her interest. ${ }^{4}$ Tamura's family lived in Idaho, outside the exclusion area, and never spent time in the camps. She recalls few if any family discussions of the incarceration growing up. ${ }^{5}$

If Maruyama in San Diego and Tamura in Idaho could grow up not knowing much about the Japanese incarceration, the same lack of knowledge is much more likely the case outside the Japanese American community and away from the West Coast, this despite the large body of scholarship on the Internment as well as feature length films going back to the 1950s, awardwinning poetry collections, best-selling novels, a vast collection of memoirs and oral histories. Allegiance, a musical starring George Takei, roughly based on Takei's own experience as a boy when his family was detained at camps in California and Arkansas, made its Broadway premiere 8 November 2015. Less than a month later, on 2 December 2015, a Pakistani American couple shot and killed fourteen people and seriously injured twenty-two more in a terrorist attack in San Bernardino, California. On 7 December 2015 - the 74th anniversary of the Japanese attack on Pearl Harbor-Donald Trump proposed a ban on all Muslim immigrants. The next day, when asked by a Time magazine reporter if he would have supported the Japanese internment, Trump said he didn't know. "I would have had to be there at the time to tell you, to give you a proper answer (...) I certainly hate the concept of it. But I would have had to be there at the time to give you a proper answer." ${ }^{6}$ In mid-November, the President's transition team cited the Japanese internment as a precedent for activating a new (or newly improved) registry for Muslims. ${ }^{7}$ George Takei

4 Wendy Maruyama, “O.E. 9066," Wendy Maruyama, 24 October 2016, http://wendymaruyama. com/section/75073-E-O-go66.html.

5 There is also a rich photographic record, especially of Manzanar, and museums and digital archives that extensively focus on the Japanese American experience during World War II.

6 Michael Scherer, "Donald Trump Says He Might Have Supported the Japanese Internment," Time, 8 December 2015, accessed 27 July 2017, http://time.com/4140050/ donald-trump-muslims-japanese-internment.

7 Derek Hawkins, "Japanese American Internment Is 'Precedent for National Muslim Registry,' Prominent Trump Backer Says," The Washington Post, 18 November 2016, https://www .washingtonpost.com/news/morning-mix/wp/2016/11/17/japanese-internment-is -precedent-for-national-muslim-registry-prominent-trump-backer-says/?utm_term $=. f_{4} 8 \mathrm{gb} 68 \mathrm{dof} 27$. 
extended a standing invitation to Donald Trump to see Allegiance, but received no reply. ${ }^{8}$

\section{Takuichi Fujii}

I travelled from northwest Indiana to Boise, Idaho to see the paintings by Takuichi Fujii, and I wished I had been able to see more. Of the eighty works that art historian and curator Barbara Johns had organized for a travelling exhibition of Fujii's work, about a dozen of his watercolours were selected by Herden and Black for the Minidoka exhibition in Boise. ${ }^{9}$ That said, the whole exhibition at the Boise Art Museum was greater than the sum of the parts. Though the featured artists are of different generations, work in different media, and employ very different styles and modes of representation, the exhibition achieved a wonderful coherence and sense of connectedness. Fujii's watercolours appeared in the exhibition courtesy of his grandson, retired professor of art history and Japanese print expert Sandy Kita, and his spouse, teacher, anthropologist, and Japanese doll scholar Terry Kita. Sandy Kita received the watercolours in 1987 from his mother, Mary Rose Satoko Kita, Fujii's eldest daughter, as part of a large cache of over a hundred paintings, drawings, and sculptures. For the past forty years, it had been assumed that Fujii, once a well-regarded Issei member of a prominent circle of Seattle painters, had stopped making art after he left the camp. The cache of artwork Kita received from his mother put that assumption to rest, and what a thrill to see his work on exhibit again after so many years. Somewhat lost in the fanfare was the presence of Fujii's art diary in the exhibition. ${ }^{10}$ It sat there on a table in a corner under a vitrine with a computer beside it providing access to a digitalized copy.

In the foreword to The Hope of Another Spring: Takuichi Fujii, Artist and Wartime Witness by curator Barbara Johns, us immigration historian Roger Daniels calls Fujii's art diary "the most remarkable document created by a Japanese

8 Ester Lee, "George Takei Calls Out Donald Trump for Japanese-American Internment Camp Comments," Us Weekly, 10 December 2015, accessed 21 July 2017, http:// www.usmagazine.com/celebrity-news/news/george-takei-calls-out-donald-trump -for-japanese-internment-comments-w159401.

$9 \quad$ For more on the larger travelling exhibition curated by Johns, Takuichi Fujii: Witness to Wartime, see http://www.curatorial.org/takuichi-fujii.

10 Dark blue and hard-bound, with "Klip and Note" inscribed in capital letters on the cover, the diary declares itself in a smaller font a receptacle for "Notes, recipes, memos, newspaper, magazine etc." 
American prisoner during the wartime incarceration."11 Given Daniel's stature, the depth of his knowledge about the incarceration and literature about it, that's saying something. In his introduction to the art diary for Johns' book, Sandy Kita, a scholar of Japanese art and Ukiyo-e print culture (and Fujii's grandson), draws upon the scholarship of Earl Minor to situate Fujii's art diary in the Japanese tradition of the e-nikki genre he appropriates and adapts. It is also possible to see similarities linking Fujii's art diary more broadly to the travel diaries of Matsuo Basho. Most of the watercolours in the exhibition began as pen and ink drawings in the diary. One on display (untitled) takes us into the train that transported Fujii and his family from the Puyallup Assembly Center to Minidoka, revealing the crowded interior of the car as a bare-chested man comes down the aisle with a small boy on his shoulders. In the vast collection of images from the incarceration, Fujii's may be the best and only images we have that show us what it looked and felt like inside those sealed up cars. It is but one example of many that suggest the visual record of the incarceration that Fujii's diary provides is like no other.

Other watercolours provide oddly an insider's view of the outside-of the camp, that is. At Minidoka, the fence was not finished when incarcerees arrived. The camp was so vast, and in the middle of the desert a fence served little purpose. Where would they go? Not long after the guard towers were built they were abandoned for the same reason. Fujii's diary frequently shows him hiking in the Idaho desert with his wife. His diary fills up with sketches of skulls, carcasses, a variety of flora and fauna, and vivid images of that harsh, desolate landscape. To see his self-portraits-fishing at the Snake River, or out in the desert on a quest to capture an owl-it is possible to forget the war, and that he and his wife are prisoners. In a pair of watercolours framed together (untitled), we see part of an adventure Fujii recorded in the diary when he was bitten by a snake out in the desert. Fujii's episodic rendering of this incident shows both of the influence of comic books - perhaps American, perhaps Japanese, perhaps both - and the development of his skills as a narrative artist. Fujii's attempt to render what he saw as a result of the snakebite inspired his first abstract expressionist image, this before the term was even coined. The whole episode which ended with an unfortunate snake bite, rendered in six drawings in the diary, fits into a much larger thematic, where we observe how Fujii begins to draw himself, literally and figuratively, out of the camp, which is to say, out of the psychological and spiritual sense of confinement so dominant earlier in his diary.

11 Roger Daniels, foreword to The Hope of Another Spring: Takuichi Fujii, Artist and Wartime Witness by Barbara John, pp. vii-viii, (Seattle: University of Washington Press, 2017). 
This tendency in Fujii's art towards abstraction can be seen in Minidoka, Montage with Fence and Landmarks, an undated watercolour montage in a cubist style that draws together features of the camp he must have seen as most recognizable and symbolic (fig. 1). Behind a pick and a planted shovelicons of the heavy labour detainees performed reclaiming the desert-the stone reception centre can be seen through a barbed wire fence-a strange, densely packed composition full of jarring juxtapositions characteristic of $\mathrm{Fu}-$ jii's art. We see the watchtower at the entrance of the camp, what seems to be a bridge crossing the North Canal, and, in the foreground, a huge water tower seemingly about to topple. A large smokestack in the background looms above the hospital. Sagebrush bursts into bloom, and a swing set and the backstop for a baseball field appear nearby: signs of life burgeoning forth in a spirit of youthfulness and play, despite the circumstances.

In contrast, no life burgeons forth, only smoke and men talking under their breath in Minidoka, Immigration \& Naturalization Officers, a work that evokes a prescient timeliness for me more than any other in the exhibit (fig. 2). There is such starkness in the landscape, and something sinister in the appearance of the two men in greatcoats conversing in the foreground, their faces as windowless as the grey buildings behind them, a single smokestack rising into a leaden sky.

In both words and images, Fujii's art diary begins in front of his flower shop on the corner of 12th Avenue and Yesler Way in Seattle, with bystanders gathered around a telephone pole reading General John L. DeWitt's posted order of exclusion of "all persons of Japanese descent, aliens and non-aliens" in late March of 1942. "Non-aliens," of course, is a strange, tortured way of not saying "(American) citizens" as "assembly center" is a way of not saying "holding pen," as "relocation center" is a way of not saying "prison." The diary ends 388 pages later in Hunt, Idaho, in a nearly abandoned camp as it was being evacuated in October of 1945. In the 252 illustrations that make up the diary (not including a title page, a frontispiece, and two watercolours), Fujii shows us every aspect of life in the camps where he was detained. Before Japanese residents were placed in the camps they were forced by the Wartime Civil Control Administration (WCCA) to surrender their cameras, so controlling the visual record of the camps was a government priority from the outset. Whatever photos the military or the civilian War Relocation Administration allowed or commissioned in the camps were carefully controlled and censored. Ansel Adams and Dorothea Lange, who were invited by the us government to take photographs, were under strict orders at Manzanar not to include barbed wire fences, watchtowers, or armed soldiers in their images. Most of Lange's photographs were impounded, in fact, even though she adhered to such restrictions. Fujii-uncensored 


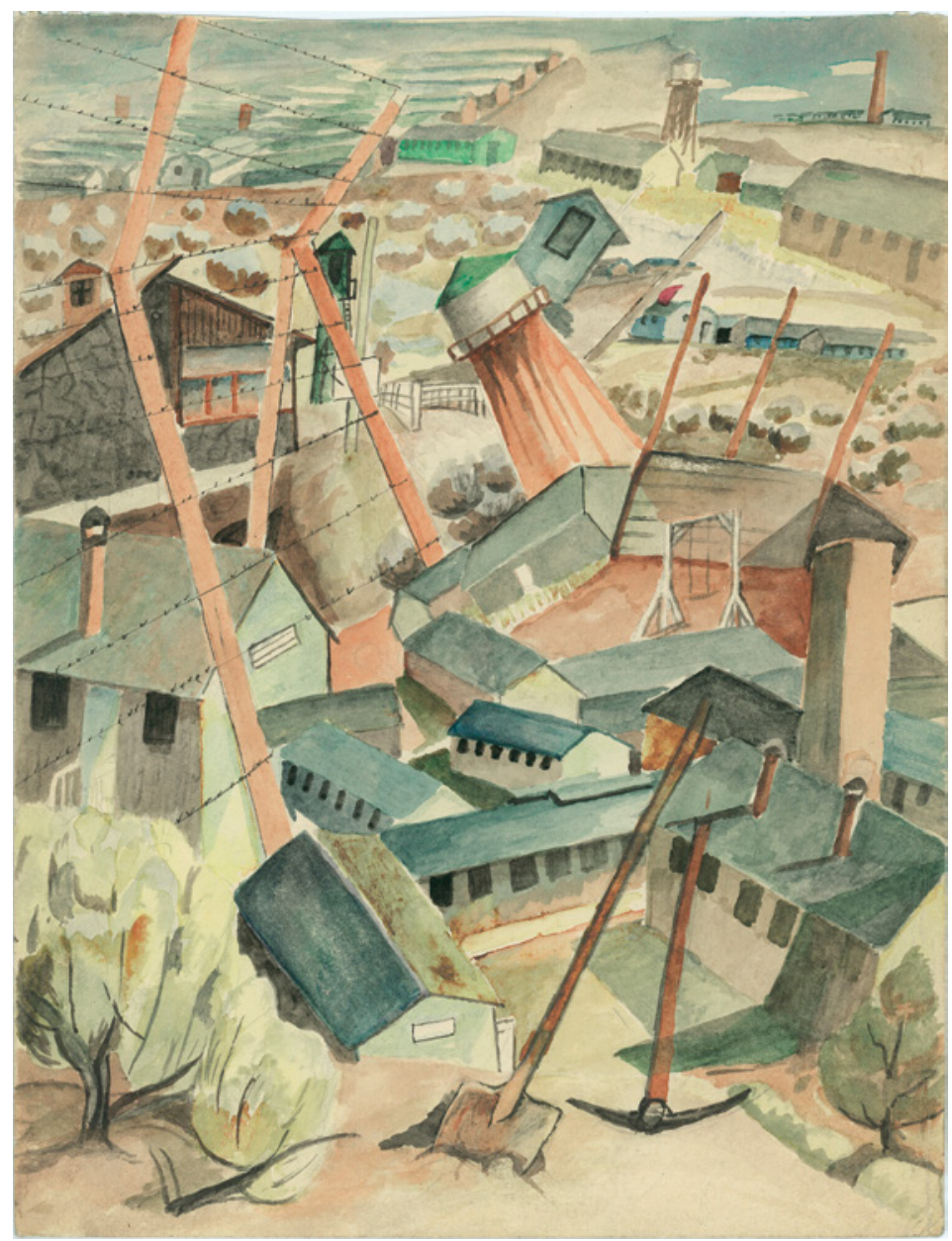

FIGURE 1 Takuichi Fujii, Minidoka, Montage with Fence and Landmarks, n.d., watercolour on paper, $11.5 \times 9$ inches $(29.2 \times 22.9$ centimetres $)$. COLLECTION OF SANDY AND TERRY KITA.

and never self-censoring, very mobile, incurably observant, and highly skilledfrequently included barbed wire fences, watchtowers, and armed guards in his drawings, sometimes all three appear in a single image. He takes us into the fully occupied men's latrines that had no partitions for privacy, into filthy public showers, into cattle stalls converted to living quarters (one per family), into tarpaper-covered shacks without running water or furniture. He also takes us to the mess hall, the barbershop, baseball games, sumo-wrestling tournaments, art exhibits, kindergarten, the Buddhist temple and the cabbage patch. It's all there: everyday life in the camp in all of its human complexity. 


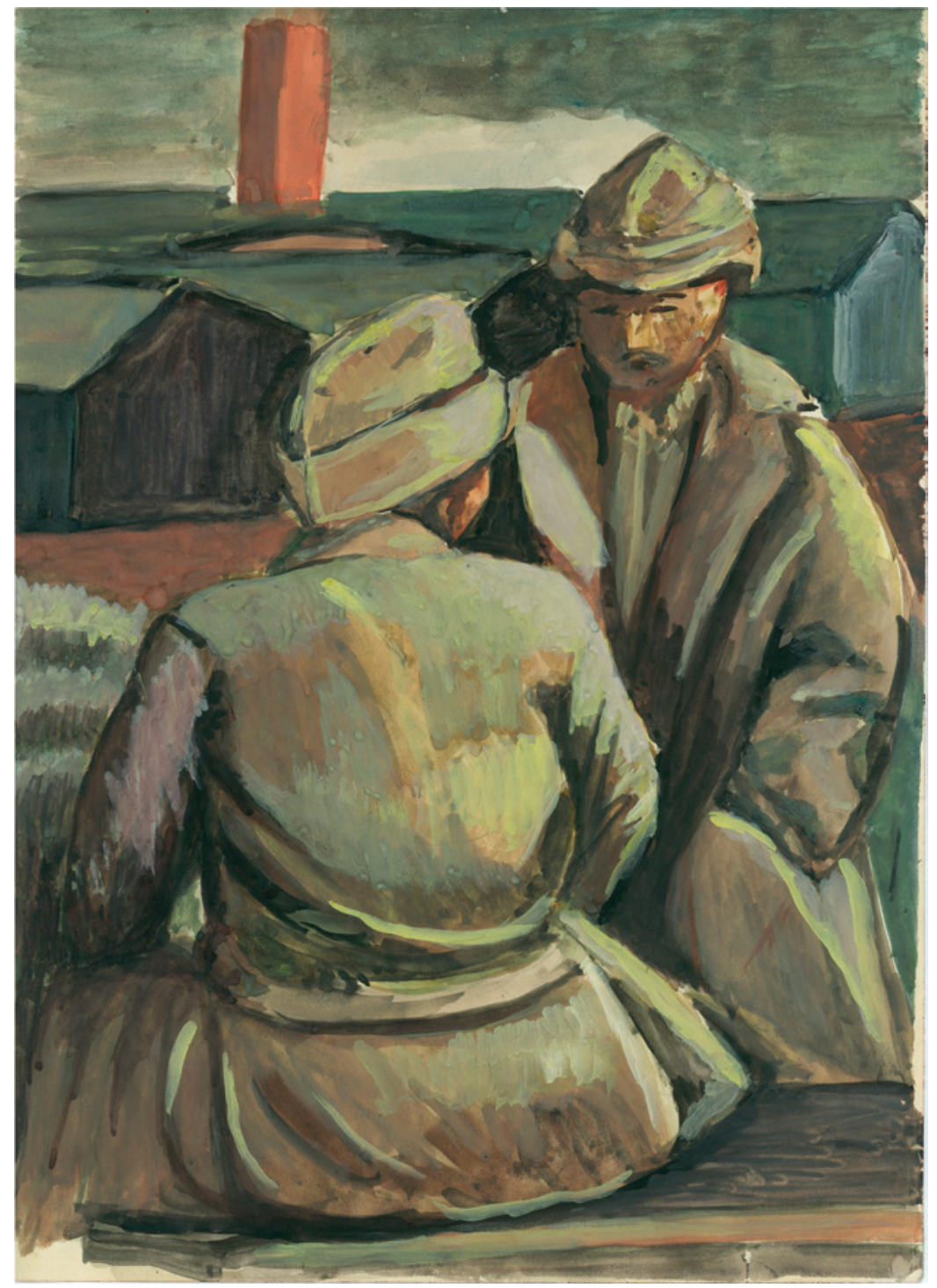

FIGURE 2 Takuichi Fujii, Minidoka, Immigration \& Naturalization Service Officers, n.d., watercolour on paper, $12 \times 8$ inches $(30.5 \times 20.3$ centimetres $)$.

COLLECTION OF SANDY AND TERRY KITA.

When Fujii arrived at the "assembly center" at Puyallup, he was an established painter but not a narrative artist; when he left Minidoka three and half years later he was an extremely skillful one. Fujii's art diary captures in both words and images not only the tragic cruelty and injustice of the incarceration, but also, with equal skill and penetration, that triumph of the human 
spirit that the Japanese American community achieved through those dark years.

\section{Kenjiro Nomura}

Kenjiro Nomura, a contemporary of Fujii from Seattle, is well represented in the exhibition with a dozen watercolours. Nomura is very highly regarded among the Seattle Issei artists who were sent to the camps. Before the war he associated with Pacific Northwest artists and exhibited in solo and group exhibitions at prestigious venues, including the Seattle Museum of Art, the Henry Gallery at the University of Washington, the Corcoran in Washington, D.C., and the Museum of Modern Art in New York. As is the case with Fujii, the watercolours on exhibit, on loan from the Tacoma Museum of Art, only came to light in the late 1980s, decades after the war ended and after Nomura had died, and were probably never intended for public exhibition. ${ }^{12}$ Though Nomura's paintings depicted the barbed wire fence, the armed guard, and the watchtower so much on Fujii's mind early in his art diary, it seems Nomura's watercolours deal as much with the feeling of abandonment as confinement, especially at Minidoka. At Puyallup, he draws upon his considerable skills as an urban scene painter to depict crowds of people, or sometimes isolated individuals, standing around or dream-walking through their day-to-day existence in a weird makeshift city of wooden shacks. The garbage cans, which Nomura lines up in these paintings, are particularly evocative. It was his job as the camp's sign painter to mark garbage cans with the letter " $\mathrm{A}$ "-for Area A, a set of hastily built barracks constructed in a parking lot at the Puyallup fairgrounds where he and his family were forced to live.

At Minidoka, it is the Idaho desert that he makes so imposing, the horizon in Guard Tower (1943) broken only by iconic Minidoka landmarks, the water tower, the smokestack, and the guard tower (fig. 3). Sometimes he paints rows upon rows of barracks receding into the distance but no people, or a single individual walking down an empty road or entering a building. The sense of isolation and alienation in these images is palpable and profound. Nomura is an urban scene painter in exile, whose works register the great absence of that city from which he had been unjustly removed just as his career was taking off. 


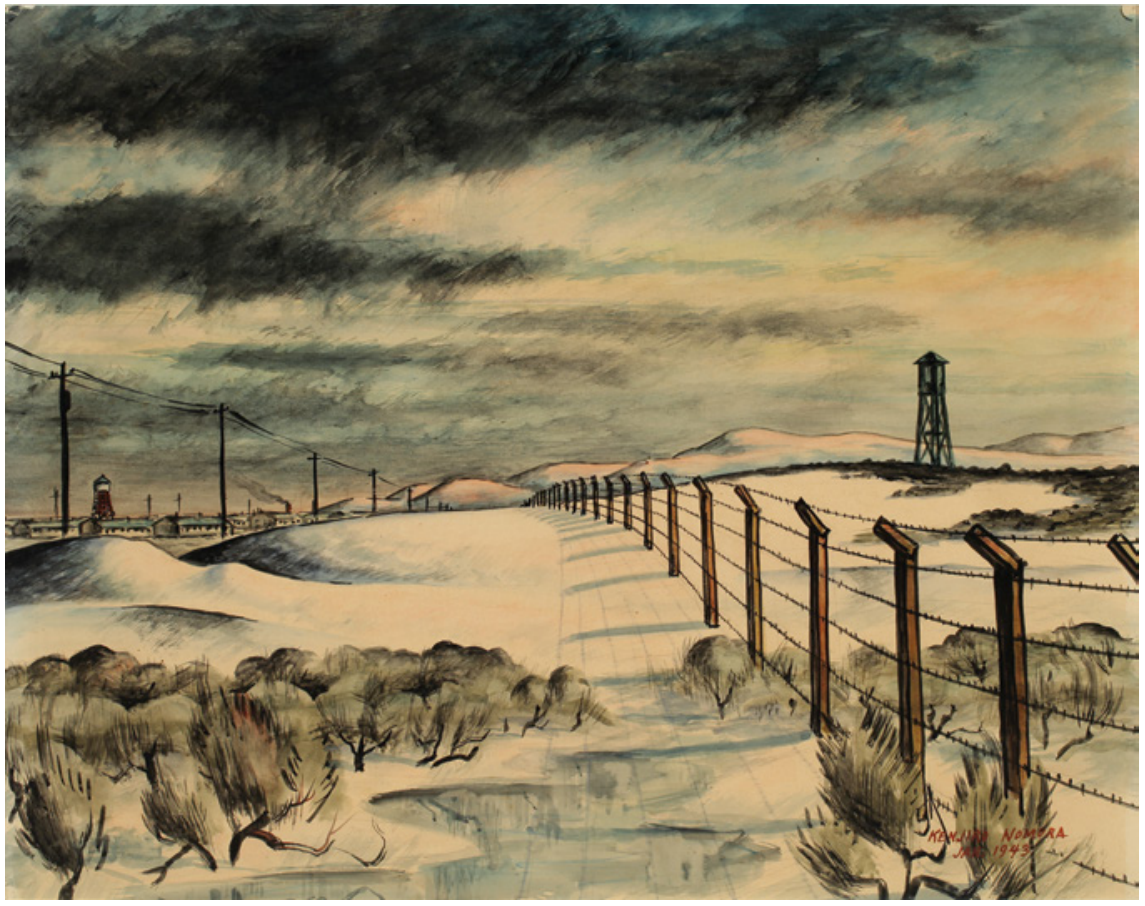

FIGURE 3 Kenjiro Nomura, Guard Tower, 1943, oil on paper, $19 \times 24$ inches $(48.3 \mathrm{~cm} \times 6$ centimetres).

THE GEORGE AND BETTY NOMURA COLLECTION, TACOMA ART MUSEUM.

\section{Roger Shimomura}

Roger Shimomura, painter and Professor of Art Emeritus at the University of Kansas, is internationally known, his works widely collected, and he has an extensive body of work on Minidoka that goes back decades. Shimomura developed a distinctive artistic language that strikes me as visually bilingual, American and Japanese, an ambidextrous multicultural (and sometimes highly combustible) mode of image making, with one hand busily drawing from Ukiyo-e print block and other Japanese artistic traditions, and the other drawing from Pop Art. Some of his work is darkly comic, hyperbolic, and sharply satirical as he boldly confronts all manifestations of anti-Japanese stereotyping and racism. That said, there is nothing comical or hyperbolic in the paintings in the exhibition about life at Minidoka; the influence from Japanese art seems more understated, and the satire more muted than in other series he has done on Minidoka. In his painting Classmates, No. 4 (2006), two young women stand on either side of a barbed wire fence: a young Caucasian woman taking her 
first big bite of an apple, and the other, a young person of Japanese heritage, still looking at hers-as a powerful an image of an American loss of innocence as I can think of. Most of the images are, in fact, similarly "barbed." Barbed wire is not only an iconic presence in Shimomura's works; it also serves as a dominant design element. This is true of twelve of the fourteen paintings in the exhibition, including Furlough (2007), a large painting of a Japanese American soldier in uniform, home on leave, facing the fence that confines him and his family in barracks we see in the distance.

Despite the barbed wire the paintings do their work quietly, with an often lyric decorum that honours the quiet dignity with which ordinary people are shown enduring the trials and humiliations of life in the camp. American Infamy \#2 (2006), the largest of the paintings, puts the camp beneath us, from the vantage point of a watchtower, with the silhouette of an armed guard watching beneath him through his binoculars. It reminded me of a Bruegel painting, how the suffering takes place inconspicuously over in the corner, though the four-panel format was derived from a Muromachiera Japanese byobu screen painting. ${ }^{13}$ In Line Up (2006), the depiction of a long line of men and boys waiting to use the latrine seems similar to Norman Rockwell's American Scene paintings, though with Shimomura, the colours are livelier and the irony much sharper (fig. 4). The title of the painting evokes for

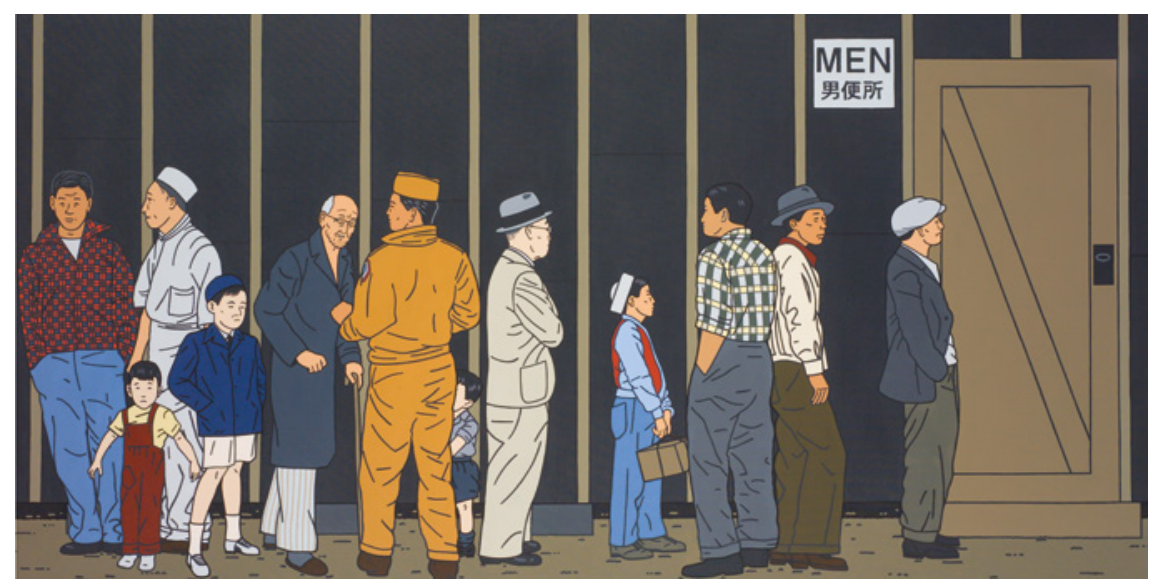

FIGURE 4 Roger Shimomura, The Lineup, 2006, acrylic on canvas, $38 \times 74$ inches $(96.5 \times 188$ centimetres).

COURTESY OF THE ARTIST.

13 Greg Kucera Gallery, "Roger Shimomura: Small Paintings, Minidoka On My Mind," accessed 27 July 2017, http://www.gregkucera.com/shimomura_minidoka.htm. 
me the idea of a police lineup, in which all of these characters, little boys, old grandpas, the cook from the mess hall, even a soldier on leave-especially that soldier on leave-become "the usual suspects" from which we are expected to pick the criminal. Of course, what is criminal is the unjust treatment such people were made to endure.

\section{Wendy Maruyama}

The first work in the exhibition that visitors encounter is an installation by San Diego-based contemporary artist and fine art furniture maker Wendy Maruyama (b. 1952). Ten eleven-foot-tall tubular sculptures that hang from the ceiling, one for each incarceration camp, are the results of her Tag Project from 2011 (fig. 5). Maruyama's website explains how the installation was completed while she was doing research for her work EO 9066 Portfolio (2008), named for the Executive Order 9066 that President Roosevelt signed on 19 February 1942 to authorize the Japanese American incarceration.

Suspended a foot above the ground, the sculptures of the Tag Project resemble Christmas trees wrapped in twine for shipment, though they are manilacoloured, each comprised of small paper tags, around 120,000 in all, replicas of the ones detainees were forced to wear while in transit to the camps. Using government databases, and with organizational assistance from the Japanese American Historical Society of San Diego, Maruyama and "hundreds of volunteers" working together "at museums, schools, churches, temples, and other non-profit organizations" helped "stamp, write, tie, [and] age the tags."14 On the artist's webpage, a video by Xavier Vasquez captures the laborious process, which Maruyama likened to a form of meditation. ${ }^{15}$ Her work deftly makes real, visible, and palpable the statistic: 120,000 people detained.

The EO go66 Portfolio, displayed in another gallery, also incorporated prominent image transfers of photographs of Manzanar by Dorothea Lange and Toyo Miyatake, whose work provoked Maruyama to explore the camps as a subject. Comprised of a number of mounted wooden cabinets and assemblages, the installation showcases iconic words, photographs, found objects, and materials associated with the camps.

Maruyama's use of physical and cultural materials is haunting and subtle, recalling ways in which Japanese Americans quickly came together to create a

\footnotetext{
14 Wendy Maruyama, email message to author, 20 December 2016.

15 Xavier Vasquez (XavaZ), "Tag Project | Poston," Vimeo, uploaded 15 January 2010, accessed 27 July 2017, https://vimeo.com/8774422.
} 


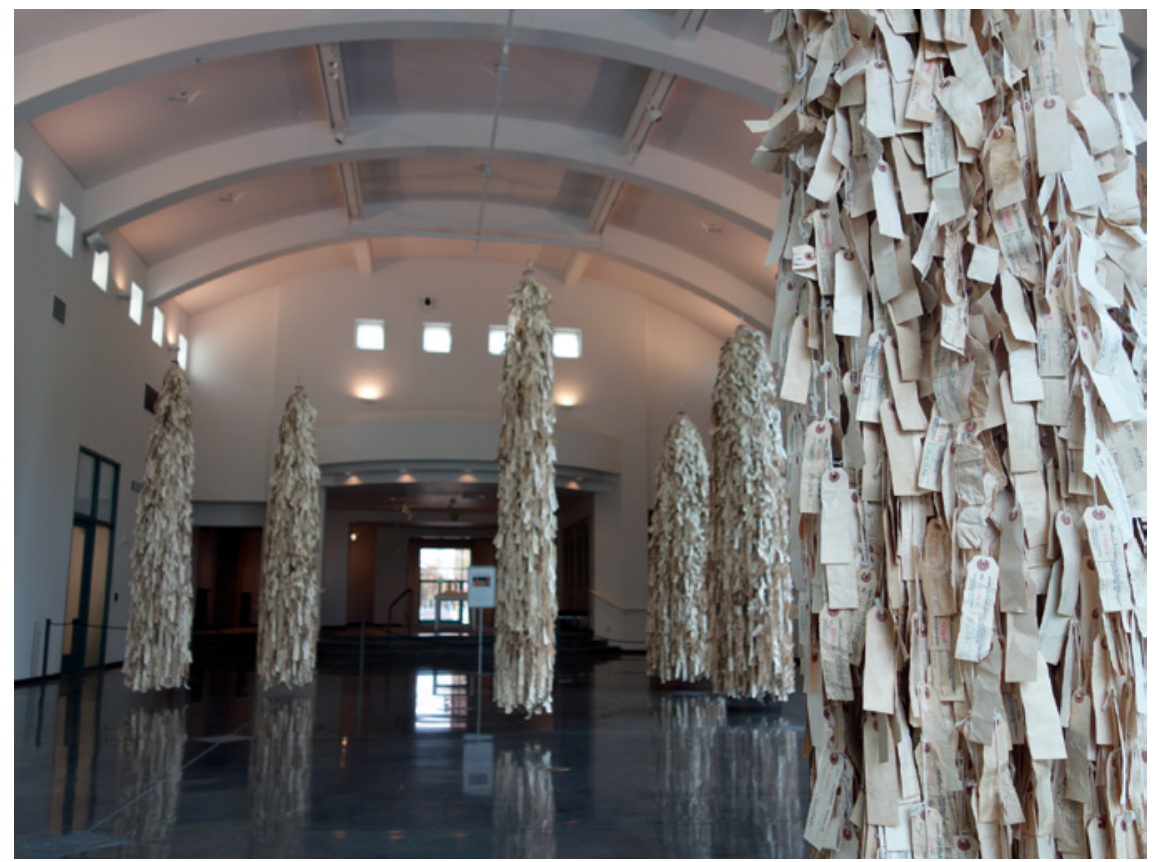

Figure 5 Wendy Maruyama, The Tag Project, installation view at the Boise Art Museum, 2011, paper, ink, string, thread, approximately $132 \times 10 \times 10$ inches each $(335.3 \times 25.4 \times 25.4$ centimetres).

COURTESy OF THE ARTIST. IMAGE PROVIDED By THE BOISE ART MUSEUM. IMAGE CREDIT: HANA VAN HUFFEL.

liveable sense of home. In the camps, residents had no furniture when they arrived beyond metal cots and a woodstove; as such, furniture making became a craft everyone engaged in. At Minidoka, for example, internationally renowned furniture maker George Nakashima (1905-1990) met the Japanese woodworker Gentaro Hikogawa (1902-1963) whose influence forever changed the meaning and direction of Nakashima's work. Maruyama has become friends with Nakashima's daughter, Mira Nakashima (b. 1942), also a fine arts furniture maker. Together they carry on an important legacy of Minidoka. In 1980, Maruyama became one of the first two women to receive an MFA in Furniture Making from the Rochester Institute of Technology.

\section{Teresa Tamura}

The work Fumiko Hayashida and Daughter, Kayo Natalie Ong (2003) by contemporary photojournalist Teresa Tamura (b. 196o) connects Minidoka's past 
to the present. The artist reproduced a famous War Relocation Administration (WRA) photograph taken in 1942 of a mother and her child as they are being sent to a camp, wearing identification tags similar to those Maruyama references in her work. She then paired this image with her own stunning blackand-white portrait of that same mother and daughter some sixty years later (figs. 6-7). Tamura captures the same reception centre that Fujii painted in the 1940s - now in ruins - in an eerie infrared landscape photograph. She ties the exhibition together with a portrait of Roger Shimomura taken at the Boise Art Museum during an earlier exhibition of his work on Minidoka. Tamura's photograph of the artist shows him standing in front of a wall between two images of his grandmother. To his left hangs a photograph of his grandmother as a picture-bride; to the right hangs his painting of her in his Ukiyo-e style. Beneath this photo Tamura has placed what seems to be a wRA photograph of Shimomura as a five-year-old with his classmates in front of their school at Minidoka. This portrait has special artistic and genealogical significance, as it was at that exhibit of paintings inspired by his grandmother's diary where Shimomura urged Tamura to follow in his footsteps, putting words and images together for her project on Minidoka, unaware they would follow a trail Takuichi Fujii blazed decades earlier.

Tamura, originally from Nampa, Idaho, and out of the exclusion zone, grew up knowing relatively little about the Japanese incarceration. It was an article in the Seattle Times about President Bill Clinton declaring Minidoka a National Park Service unit in January 2001 that first directed Tamura's attention to Minidoka. At the time, she was working as a photojournalist and photography teacher. As she relates in the preface to her book, Minidoka: An American Concentration Camp: "The story took me by surprise. I thought about growing up in Nampa, Idaho, less than three hours from Minidoka, and asked myself why, in my forty years, I had never seen the site."16 When she looked for books specifically about Minidoka she was unable to find any. Thankfully, that situation has changed, and her own book, published in 2013, makes a significant contribution to the growing corpus by providing a rich, coherent, and thoroughly researched photographic record of the lived experience of Minidoka residents in their own words, from the attack on Pearl Harbor, through the period of incarceration, to the present.

During its short run, the exhibition Minidoka: Artist as Witness had the powerful potential to help us learn from Japanese Americans who survived the

16 Teresa Tamura, introduction to Minidoka: An American Concentration Camp (Caldwell: Caxton Press, 2013), i. 


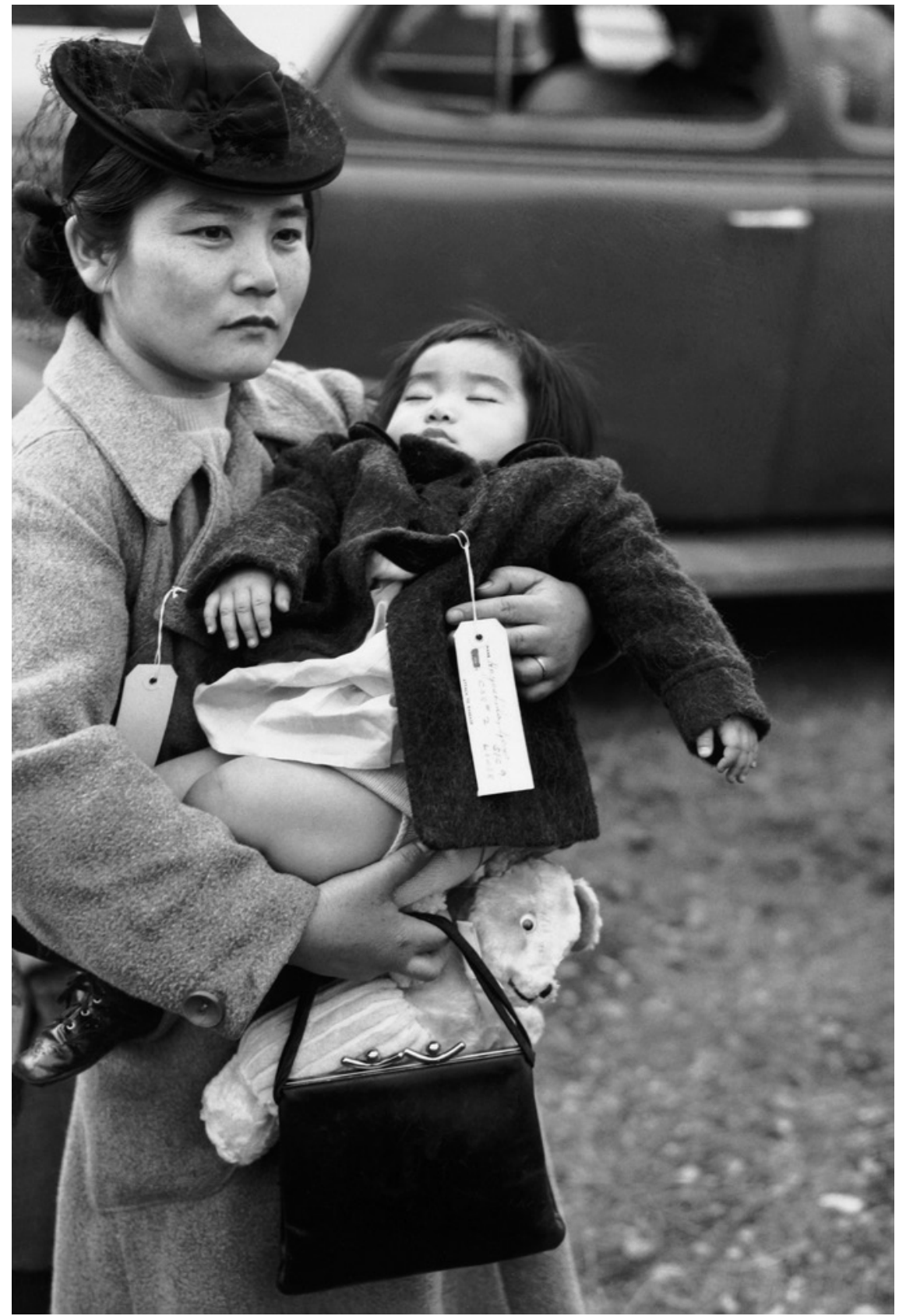

FIGURE 6 Photographer unknown (staff photographer, Seattle Post-Intelligencer), Fumiko Hayashida and her daughter, Bainbridge Island, zo March 1942. MOHAI, Seattle Post-Intelligencer PHOTOGRAPH COLLECTION, PI28050. 


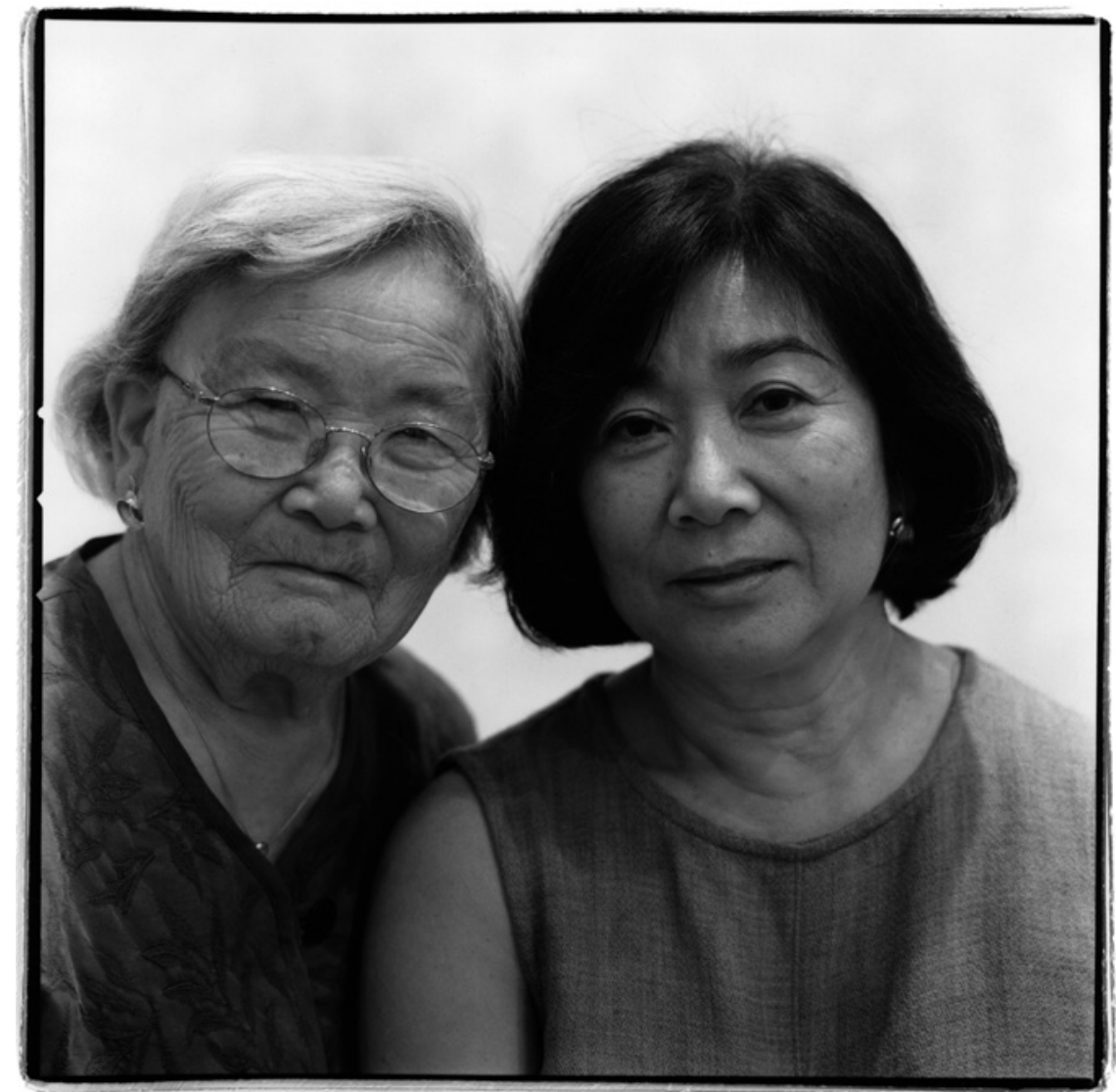

FIGURE 7 Teresa Tamura, Fumiko Hayashida and Daughter, Kayo Natalie Ong, 2003, gelatin silver print from 120 black-and-white Tri-X film,10.2 inches $\times 10.2$ inches $(26 \mathrm{~cm} \times 26 \mathrm{~cm})$.

COURTESY OF THE ARTIST.

internment camps, and how they-and generations after them-have endured and continue to redress this legacy of injustice.

Boise, Idaho, was a long way for me to travel to see the show. It is a pity it did not travel for others to more easily see the exhibition, given the excellence of the artists and the relevance, and urgency of their shared witness. The exhibit existed to help us see and feel how important it is we never forget wrongs that were committed through fear, ignorance, and a nation's failure to live up to its own best principles. It existed to help us learn from those who survived incarceration how to endure, even thrive together through times of darkness and suffering. 
John R. Ruff

is a poet and a Professor of English at Valparaiso University in Northwest Indiana. He teaches a variety of courses in American literature and Asian American studies, including courses on Asian American writers, American literatures of immigration, and Sino-American understanding of spirit and place. Presently he is working a book of poetry and prose inspired by the Art Diary of Takuichi Fujii.

\section{References}

Chew, Ron. Foreword to Kenjiro Nomura: An Artist's View of the Japanese American Internment, by June Mukai McKivor. Seattle: Wing Luke Asian Museum, 1991.

Daniels, Roger. Foreword to The Hope of Another Spring: Takuichi Fujii, Artist and Wartime Witness by Barbara John, pp. vii-viii, Seattle: University of Washington Press, 2017.

Fujii, Takuichi. The Art Diary of Takuichi Fujii, intro. Sandy Kita, trans. Kita and Honda Shojo, 2011.

Tamura, Teresa. Minidoka: An American Concentration Camp. Caldwell: Caxton Press, 2013. 